\title{
INTERAKSI BUDAYA ANTARA AUSTRONESIA DENGAN NON AUSTRONESIA MEMENGARUHI PERKEMBANGAN TEKNOLOGI DI MASA AUSTRONESIA
}

\section{Cultural Interaction between Austronesia and Nonaustronesia Affecting to Development of Technology in Austronesia Period}

\author{
Zukhrufa Ken Satya Dien \\ Universitas Negeri Yogyakarta \\ Jalan Colombo No.1, Karang Malang, Caturtunggal, Kec. Depok, Sleman \\ Daerah Istimewa Yogyakarta 55281
}

E-mail: kenufa.zukhrufa@gmail.com

\begin{abstract}
Indonesia is a part of Austronesian civilization. Previously Austronesian civilization originated from Taiwan, where many theories about this were followed by researchers who supported the existence of Austronesian cultural civilization. The popularity of the theory is inseparable from the support of linguistic data, anthropology, DNA, dating and archaeological data. Inter-cultural interaction between Austronesian colonization in the Indonesian Archipelago can be summarized in the culture of the coming neolithic era in the Indonesian Archipelago, the culture is carried by the Austronesian-speaking community. As a result of these events, there was a development of Neolithic culture in the Indonesian Archipelago, an evolution and interaction between Austronesian migrant communities and Non-Austronesian communities that had inhabited this region since earlier times. When Austronesian people arrived in the Non-Austronesian region, the Non-Austronesian community also had more or less the same knowledge as the Austronesian people and even more adaptive in some technological mastery such as shells and bone tools, shipping technology, technology in the cultivation of tuber plants.
\end{abstract}

Keywords: Austronesian, Non Austronesian, Interaction, Austronesian civilization technology

\section{AbSTRAK}

Indonesia merupakan salah satu bagian dari peradaban Austronesia. Sebelumnya peradaban Austronesia berasal dari Taiwan yang mana teori mengenai ini banyak diikuti oleh peneliti yang mendukung adanya peradaban budaya Austronesia. Populernya teori tersebut tidak lepas dari dukungan data linguistik, antropologi, DNA, pertanggalan dan data dari arkeologis. Interaksi antar budaya yang kolonisasi Austronesia di Kepulauan Indonesia dapat dirangkum dalam kebudayaan masa neolitik datang di Kepulauan Indonesia, budaya tersebut di bawa oleh masyarakat penutur bahasa Austronesia. Akibat dari peristiwa tersebut, terjadi perkembangan budaya Neolitik di Kepulauan Indonesia, terjadinya evolusi dan interaksi antara masyarakat pendatang Austronesia dengan komunitas Non Austronesia yang telah menghuni kawasan ini sejak masa sebelumnya. Ketika masyarakat Austronesia datang di kawasan Non Austronesia, komunitas Non Austronesia juga telah memiliki pengetahuan yang kurang lebih sama dengan bangsa Austronesia bahkan lebih bersifat adaptif dalam beberapa penguasaan teknologi seperti alat kerang dan alat tulang, teknologi pelayaran, teknologi dalam pembudidayaan tanaman umbi-umbian.

Kata kunci: Austronesia, Non Austronesia, Interaksi, teknologi peradaban Austrones 


\section{PENDAHULUAN}

$\mathrm{K}$ ajian mengenai sebuah peradaban Austronesia sudah berlangsung lama. Para ilmuwan Indonesia berpendapat bahwa persebaran rumpun bahasa Austronesia atau bangsa Austronesia ini disebabkan oleh proses ekspansi masyarakat penutur Austronesia ke luar dari daerah asalnya akibat dari sebuah tekanan demografi. Ternyata banyak sekali ilmuwan yang berpendapat dan mengemukakan sebuah teori mengenai perdaban Austronesia, teori tersebut antara lain rumpun Austronesia berasal dari Taiwan, rumpun Austronesia berasal dari Asia Tenggara Kepulauan, dan rumpun Austronesia berasal dari Malanesia. ${ }^{1}$

Hasil sebuah penelitian mengenai peradaban Austronesia tertua di Indonesia berada di Pulau Sulawesi. Penelitian yang dilakukan oleh ilmuwan ini diperoleh dari sebuah pertanggalan situs Minanga Sipakko di Sulawesi Barat. Hal ini membuat Sulawesi menjadi peradaban penting dari rumpun Austronesia masa prasejarah. Situs persebaran peradaban Austronesia tidak hanya di wilayah kepulauan Sulawesi saja, akan tetapi situs persebaran peradaban Austronesia ini juga kewilayah Leang Tuwo Mane'e 3.500 Bp, Uattamdi 3.200 Bp, Kendenglembu, di Jawa Timur dan di Kendenglembu ternyata hanya menghasilkan petanggalan $1.300 \mathrm{Bp} .2$ Asal mula rumpun

1 Bellwood, P. 1995.“'Austronesian Prehistory in Southeast Asia: Homeland, Expansion and Transformation", dalam Peter Bellwood, James J. Fox, Darrell Tryon (eds), The Austronesians: Historical and Comparative Perspectives, pp. 96-111, Canberra: ANU.

2 Noerwidi, Sofwan. "Migrasi Austronesia dan Implikasinya Terhadap Perkembangan Budaya di Kepulauan Indonesia”. Jurnal Penelitian dan Pengembangan Arkeologi, Vol. 21, No. 1, Juni 2014: 1-76
Austronesia banyak sekali ilmuwan yang masih mencari tahu kebenarannya. Namun, teori yang mengatakan bahwa rumpun Autronesia berasal dari Taiwan inilah yang menjadi teori paling kuat asal mula rumpun Austronesia yang melakukan migrasi keberbagai daerah. Pendapat mengenai asal mula Austronesia dari Afrika yang termasuk manusia modern sekitar 5.000 BP yang kemudian melakukan migrasi ke wilayah Timur, sehingga mendarat ke pesisir pantai China bagian selatan yang termasuk kedalam ras Monggolid, kemudian menyebar daerah ke Taiwan dan kemudian ke wilayah lainnya dibagian Selatan, tentu ada kemungkinan penyebaran Austronesia juga ke wilayah lainnya (Wilayah Barat) Penyebaran ke wilayah Barat ini kemungkinan mengikuti sebuah alur barat hingga ke Thailand, kemudian alur penyebaran peradaban rumpun Austronesia dengan cara mengikuti sebuah Sungai Perak yang alirannya dari wilayah Thailand terus sampai Kerajaan Perak Malaysia, yang pada akhirnya bermuara di Selat Malaka.

Setelah mengetahui sedikit mengenai teori peradaban rumpun Austronesia yang bermigrasi kewilayah Indonesia, pada materi ini akan membahas mengenai Interaksi antara rumpun Austronesia dengan NonAustronesia. Ternyata, sebelum rumpun Austronesia ini datang bermigrasi ke Indonesia, di beberapa pulau di Indonesia tidak sepi penduduk. Penduduk yang tinggal di kepulauan Indonesia merupakan komunitas Non-Austronesia, yang mana komunitas ini sudah eksis sebelumnya. Pada awalnya, masyarakat neolitik Austronesia tidak mudah untuk memasuki di wilayah Kepulauan Indonesia yang telah padat dihuni oleh manusia. Setidaknya sejak akhir Pleistosen sekitar 60.000 Bp Kepulauan Indonesia ini telah dihuni oleh manusia 
modern. Bukti dari penghunian manusia pada zaman prasejarah yaitu gua. Gua secara aktual diperoleh dari Gunung Sewu dengan jejak penggunaan api dan aktivitas perbengkelan menggunakan sebuah alat batu. Beberapa bukti paleoantropologis yang mengindikasikan padatnya penghunian Austronesia di Kepulauan Indonesia yang tertua mungkin adalah Tengkorak Wajak (30 Kya), kemudian beberapa rangka dari Gunung Sewu pada awal masa Helosen, rangka-rangka dari Bukit Sampah Kerang Hoabinhian di Sumatera pada zaman Holosen, di Kalimantan dan Sulawesi.3

Hal ini merupakan sebuah kegiatan kontak budaya antara penutur Austronesia dan penutur Non-Austronesia atau sebuah penduduk asli Indonesia. Dalam kegiatan kontak budaya tersebut menyebabkan terjadinya sebuah interaksi budaya diantara penutur Austronesia dengan NonAustronesia. Demikian di dalam tulisan ini akan membahas mengenai migrasi yang terjadi pada zaman Austronesia di Indonesia, selain itu membahas mengenai proses interaksi budaya antara penutur Austronesia dengan penutur Non Austronesia.

\section{PEMBAHASAN}

\section{Kebudayaan Austronesia Masa Neo- lithikum}

Penutur Austronesia memiliki kemungkinan besar datang ke Indonesia sudah sejak masa Neolithikum. Penutur Austronesia ini bermigrasi kewilayah Indonesia akibat iklim yang ekstream ditempat tinggal sebelumnya. Ketika

3 Jacob, T. 1967. "Some Problems Pertaining to the Racial History of the Indonesian Region", Disertasi Doktoral, Utrecht: Drukkerij Neerlandia. penutur Austronesia datang ke Indonesia mereka bertempat tinggal dalam gua di atas bukit, mereka bertempat tinggal diatas bukit karena mereka ingin mendekat dengan sumber air. Sebelum penutur Austronesia datang di wilayah Indonesia sudah ada penduduk asli di wilayah tersebut. Penduduk asli wilayah tersebut disebut dengan penutur Non-Austronesia. Kedatangan Penutur Austronesia di wilayah yang sudah dihuni memungkinkan terjadinya proses adaptasi dan interaksi dengan populasi asli. Bukti dari arkeologis memperlihatkan bahwa adanya percampuran budaya penghuni awal yang mencirikan kehidupan berburu dan meramu dengan budaya pendatang yang memperkenalkan produk teknologi baru, terutama tembikar dan beliung atau kapak batu.

Budaya penutur Austronesia dikenal ada pada masa Neolitik karena mereka sudah mulai tinggal menetap disebuah gua atau tempat tinggal yang menurut mereka aman untuk melindungi diri. Pada masa neolitik ini sudah tidak lagi menggantungkan hidupnya pada alam, tetapi sudah meulai mengenal alam lingkungan sekitarnya. Masyarakat mulai mengembangkan kehidupannya yang baru berupa kegiatan bercocok tanam sederhana dengan sistem slash and burn, atau terjadi perubahan dari food gathering ke food producing. Berbagai macam tumbuhan dan hewan mulai dijinakkan dan dipelihara untuk memenuhi kebutuhan protein hewani, kegiatan berburu, dan menangkap ikan masih terus dilakukan. ${ }^{4}$

Penutur Austronesia sudah mulai menunjukkan sebuah tanda-tanda cara hidup menetap di suatu tempat, berkelompok

4 Sujud, Slamet. "Prasejarah Indonesia: Tinjauan Kronologi dan Morfologi”. Jurnal Sejarah dan Budaya, No 2, Desember 2013 
membentuk perkampungan-perkampungan kecil. Di masa ini kelompok manusia sudah lebih besar, karena pertanian dan peternakan dapat memberi makan penduduk dalam jumlah yang lebih besar. Pada masa ini sudah muncul sebuah bentuk perdagangan yang bersifat barter. Barang yang dipertukarkan berupa hasil pertanian ataupun kerajinan tangan. Selain itu pada perkembangan pada bidang lain juga muncul yaitu bidang kepercayaan. Bidang kepercayaan yang dilakukan bangsa Austronesia dengan bangsa Non-Austronesia ini lebih menekankan pada sistem penguburan mayat. Kemudian, berkembang dalam bidang teknologi, pertanian dan lain sebagainya.

\section{Interaksi penutur Austronesia dengan Penutur Non Austronesia Bidang Bercocok Tanam}

Awal sebelum kedatangan penutur Austronesia kegiatan bercocok tanam yang dilakukan oleh penutur NonAustronesia masih belum berkembang. Walaupun bercocok tanam dikalangan Non-Austronesia belum berkembang, ternyata di Situs Kuk yang letaknya pada dataran tinggi bagian barat Nugini, telah menemukan indikasi perusakan vegetasi yang diakibatkan oleh aktivitas di lahan basah. Hal tersebut diasosiasikan bahwa adanya sebuah aktivitas pertanian sejak 9000 Bp dengan memanfaatkan rawa yang ada di Situs Kuk tersebut. Bahkan sistem drainase telah dikenal di situs ini sudah ada sejak $4000 \mathrm{Bp}$, untuk mengendalikan ketinggian air rawa, mereka membuat sebuah parit dengan panjang $500 \mathrm{~m}$, parit sedalam $3 \mathrm{~m}$, dan lebar parit 4,5 m. Kemudian pada tahun $3000 \mathrm{Bp}$ terdapat pertanian intensif dengan pembukaan sebuah lahan. Tanaman yang ada di Situs Kuk tersebut adalah ketela rambat.
Sebelum datangnya penutur Austronesia sudah mucul sebuah tanaman tropis yang ada di kawasan Kepulauan Indonesia antara lain keladi atau talas (Colocasia esculenta), ubi (Discorea sp), birah (Alocasia microrhiza), sukun (Artocarpus altilis), tebu (Saccarum officinarium), sagu (Metroxylon sp), kelapa (Cocos nucifera) dan beberapa spesies pisang (Musa sapientum dan Musa traglogytarum).5 Ternyata penutur Austronesia juga memakan tumbuhan ataupun buah yang berasal dari wilayah penutur Non-Austronesia. Salah satu buah yang dimakan oleh penutur NonAustronesia adalah buah pisang. Penutur Austronesia datang ke wilayah penutur Non-Austronesia dengan membawa sebuah biji-bijian untuk di tanam. Kegunaan bijibijan bagi penutur Austronesia yaitu sebagai upacara adat. Upacara adat ini masih dilaksanakan oleh masyarakat yang berada di Indonesia bagian Timur.

Ketika kedatangan penutur Austronesia, penutur Non-Austronesia sudah mulai mengenal cara bercocok tanam dengan benar. Cara bercocok tanam yang dilakukan oleh penutur Austronesia melakukan sebuah irigasi pada ladang atau di kebun, selain itu mereka juga bercocok tanam dengan cara melihat sebuah iklim yang ada di daerah tersebut. Hal tersebut sangat memberikan sebuah berpengaruh besar bagi penutur Non-Austronesia di wilayah kepulauan Indonesia, karena di Indonesia memiliki iklim yang bervariasi. Iklim di bagian Pulau Sumatera, Kalimantan dan Papua serta Jawa bagian barat dan tengah memiliki iklim tropis dengan hujan tropis yang lembab dan basah. Namun di Pulau Jawa bagian timur,

5 Ibid, Noerwidi, Sofwan. "Migrasi Austronesia dan Implikasinya Terhadap Perkembangan Budaya di Kepulauan Indonesia". Jurnal Penelitian dan Pengembangan Arkeologi, hal. 5 
Kepulauan Sunda Kecil dan Kepulauan Maluku memiliki sebuah iklim yang lebih kering karena mendapat pengaruh angin muson timur dari Benua Australia. Pada wilayah Maluku Utara memiliki curah hujan rata-rata mencapai $1.000 \mathrm{~mm}$ per tahun, dengan jumlah hari hujan antara 153-266 hari per tahun, dan suhu udara rata-rata $26,3^{\circ} \mathrm{C}$, dengan suhu udara maksimum $30,1^{\circ} \mathrm{C}$ dan suhu minimum $23,5^{\circ} \mathrm{C}$, kondisi iklim seperti itu sangat ideal bagi pertanian biji-bijian. Meskipun demikian, kecepatan angin yang tinggi dan intensitas penyinaran yang tinggi, membuat kawasan ini menjadi lebih kering, sedangkan iklim basah dengan curah hujan yang melebihi penguapan tidak terjadi dan hal tersebut menyebabkan terjadinya kegagalan dalam sebuah proses penyerbukan.6 Berdasarkan bukti yang ada tersebut dapat ditarik kesimpulan bahwa kawasan tersebut kurang cocokuntuk mengembangkan pertanian biji-bijian. Bercocok tanam yang dilakukan oleh penutur Austronesia ini menyebabkan terjadinya sebuah interaksi dengan penutur Non-Austronesia. Interaksi yang terjadi ini menjadikan perkembangan teknologi pada bidang bercocok tanam.

\section{Interaksi Penutur Austronesia dengan Penutur Non Austronesia Bidang Pe- layaran}

Berdasarkan jangkauan diaspora teknologi pelayaran, Penutur Austronesia lebih banyak menggunakan transportasi laut dibandingkan dengan transportasi darat. Sehingga terjadinya sebuah interaksi

6 Wasita. 1999. "Faktor Pendukung Budidaya Padi Masa Prasejarah", Naditira Widya No. 03, hlm. 61-69, Banjarmasin: Balai Arkeologi Banjarmasin. antara penutur Austronesia dengan penutur Non-Austronesia dalan bidang pelayaran berawal ketika penutur Austronesia berlayar ke wilayah Kepulauan Indonesia. Penutur Non-Austronesia pada awalnya juga sudah mrnggunakan navigasi pelayaran, karena Indonesia merupakan negara kepulauan sehingga membutuhkan sebuah transportasi laut untuk berpergian kewilayah lainnya. Walaupun sudah ada navigasi pelayaran di laut namun mereka belum memiliki keahlian yang lebih baik dari pada penutur Austronesia. Hal ini lah yang membuat terjadinya interaksi diantara keduanya. Ketika keduanya sudah berinteraksi maka akan menciptakan hal baru berupa pembuatan sebuah kapal untuk berlayar kewilayah lain, Karena wilayah Kepulauan Indonesia ini di dominasi dengan banyaknya perairan yang lalui untuk menghubungkan wilayah s/atu kewilayah lainnya. Interaksi ini menciptakan sebuah perahu atau kapal yang lebih baik dari sebelumnya.

Sebelumnya penutur Non-Austronesia ini sudah mengetahui teknologi pelayaran, hanya saja bentuk kapal yang digunakan oleh penutur Non-Austronesia tidak sebaik dengan kapal yang digunakan oleh penutur Austronesia ketika datang ke wilayah Kepulauan Indonesia. Kapal yang digunakan oleh penutur Non-Autronesia dalam berlayar diwilayah sekitar tempat tinggal atau pantai sekitar tempat tinggal mereka yaitu perahu bercadik. Mereka menggunakan perahu bercadik tersebut untuk melakukan penangkapan ikan. Perkembangan teknologi pelayaran pertama kali penutur Austronesia ke penutur Non-Austronesia berada di wilayah Maluku. Pembuatan sebuah kapal di Maluku ini digunakan sebagai navigasi pelayaran ke wilayah lain yang lebih jauh. Kapal yang dibuat untuk melakukan sebuah navigasi pelayaran adalah kapal Orembai. 
Bentuk dari kapal Orembai ini mirip dengan kapal yang digunakan oleh masyarakat yang ada di kepulauan Solomon dan Botel Tobago. Kapal Orembai di Maluku ini digunakan untuk navigasi persebaran penutur Austronesia diberbagai wilayah Kepulauan Indonesia maupun wilayah kepulauan lain.

\section{Bahasa Percakapan antara Penutur Austronesia dan Penutur Non Austro- nesia}

Bahasa yang digunakan untuk percakapan penutur bahasa Austronesia maupun Non-Austronesia ternyata dipengaruhi oleh dua faktor yaitu verbal dan non verbal. Pengaruh bahasa secara verbal ternyata seperti halnya pengaruh kebudayaan yang memiliki sifat jangka pendek atau tidak bertahan lama apabila tidak digunakan secara terus menerus atau ketika masyarakat sekitar tidak menerima kebudayaan tersebut. pengaruh bahasa secara verbal ini lah yang mengakibatkan bahasa yang digunakan penutur Austronesia maupun Non-Austronesia beraneka ragam bahasa. Sedangkan pengaruh bahasa secara non verbal ini berdasarkan sebuah gaya hidup dari manusia tersebut dan secara simbolis pemaknaannya lebih kuat dan dinamis. Bahasa asli dari penutur Austronesia saat ini digunakan oleh masyarakat di wilayah Maluku Utara, sedangkan bahasa asli dari penutur Non-Austronesia berasal dari wilayah Irian Jaya atau Papua. Walaupun bahasa yang digunakan antara penutur Austronesia dan penutur Non-Austronesia ini berbeda mereka tetap dapat melakukan percakapan dan interaksi satu sama lain. Bahasa yang digunakan oleh penutur Austronesia dan penutur Non-Austronesia adalah bahasa Melayu. Ternyata bahasa Melayu ini memang bahasa ibu pada zaman itu.

Ketika sudah mengetahui singkat mengenai bahasa dan penutur yang digunakan diantara kedua penutur tersebut, maka saat ini akan membahas mengenai nmasyakat dari setiap penutur. Masyarakat Ternate, Tidore dan Jailolo merupakan rumpun bahasa Non-Austronesia, sedangkan masyarakat Bacan merupakan memiliki sebuah kebudayaan dan termasuk dalam rumpun Austronesia. Asumsi linguistik menyatakan bahwa perbedaan bahasa merupakan indikasi perbedaan suku bangsa dan semakin jauh perbedaan suku bangsa maka semakin jauh pula hubungan kognitif di antaranya. Namun yang terjadi di Maluku Utara adalah sebaliknya, Bacan yang cenderung berbudaya Austronesia diikat bersama Ternate, Tidore, dan Jailolo yang Non-Austronesia dalam konsep Moluku Kie Raha. Di kawasan tersebut, Bacan merupakan bagian integral dari pola pemikiran tradisional Maluku Utara.7

\section{SIMPULAN}

Pada saat penutur bahasa Austronesia datang ke wilayah Kepulauan Indonesia, diwilayah ini tidak kosong penduduk namun, sudah ada penutur bahasa NonAustronesia yang tinggal di Kepulauan Indonesia tersebut. Terjadinya pertemuan penutur Austronesia dan penutur NonAustronesia menjadikan sebuah interaksi antar budaya. Akibat terjadinya interaksi tersebut memunculkan sebuah inovasi dan

7 Yos, Inyos. 1997. Konstruksi Posesif Bahasa-bahasa Austronesia dan Non Austronesia di Kawasan Timur Indonesia: Studi Bandingan Bahasa Tetun (Timor Timur), Lamaholot (Flores Timur), dan Mai Brat (Kepala Burut), Journal Humsniora $V$ 
perkembangan teknologi dari berbagai bidang. Perkembangan teknologi yang terjadi akibat interaksi penutur Austronesia dengan penutur Non-Autronesia ini seperti tenologi pemecah kerang, teknologi dalam pertanian dan teknologi pelayaran. Hingga saat ini masih dapat ditelusuri mengenai teknologi yang berkembang pada saat awal penutur Austronesia datang ke wilayah Kepulauan Indonesia.

Terjadinya sebuah interaksi antara penutur Austronesia dan penutur NonAustronesia ini tidak mudah, hal ini akibat bahasa yang mereka gunakan berbeda. Bahasa yang digunakan penutur Austronesia inimasih digunakan oleh penduduk di Maluku Utara, sedangkan bahasa yang digunakan penuturu Non-Austronesia adalah bahasa papua. Perbedaan bahasa tersebut pada akhirnya mengambil jalan tengah dengan menggunakan bahasa Melayu. Karena, bahasa Melayu ini mirip dengan bahasa yang digunakan oleh penutur Austronesia dan penutur Non-Austronesia, serta bahasa Melayu ini mudah diucapkan oleh kedua penutur tersebut. Ketika bahasa Melayu yang menjadi penengah interaksi antara penutur Austronesia dan Non-Austronesia maka interaksi tersebut menjadikan perkembangan teknologi hingga saat ini.

\section{DAFTAR PUSTAKA}

Bellwood, P. 1995.“Austronesian Prehistory in Southeast Asia: Homeland, Expansion and Transformation", dalam Peter Bellwood, James J. Fox, Darrell Tryon (eds), The Austronesians: Historical and Comparative Perspectives, pp. 96111, Canberra: ANU.

Carson, M. T. 2013. "Austronesian Migrations and Developments in Micronesia", Journal of Austronesian Studies 4 (1), pp. 25-35, Taiwan: National Museum of Prehistory.

Chazine, Jean-Michel dan Jean-George Ferrié. 2008. "Recent Archaeological Discoveries in East Kalimantan, Indonesia”, dalam Bulletin IndoPacific Prehistory Association No. 22, pp. 16-22, Canberra: ANU Press.

Daud Aris Tanudirjo. (2019). Teknologi dan Proses Adaptasi Lingkungan. [Direkam oleh Zukhrufa Ken Satya Dien] Pada Memo Rekaman handphone. Bandung: Seminar Nasional Arkeologi Jawa Barat

Jacob, T. 1967. "Some Problems Pertaining to the Racial History of the Indonesian Region”, Disertasi Doktoral, Utrecht: Drukkerij Neerlandia.

Ketut, Wiradnyana. "Budaya Austronesia di Indonesia bagian Barat dalam Kaitannya dengan Migrasi Out of Taiwan". Jurnal Balai Arkeologi Medan, Vol.18, No.1, April 2015: 2239

Noerwidi, Sofwan. "Migrasi Austronesia dan Implikasinya Terhadap Perkembangan Budaya di Kepulauan Indonesia”. Jurnal Penelitian dan Pengembangan Arkeologi, Vol. 21, No. 1, Juni 2014: 1-76

Sémah, F., Anne-Marie Sémah dan Magali Chacornac-Rault. 2006. "Climate and Continental Record in Island South East Asia since the Late Pleistocene: Trends in Current Research, Relationship with the Holocene Human Migration Wave", dalam Truman Simanjuntak, Inggrid H.E Pojoh, Mohammad Hisyam (ed.), Austronesian Diaspora and the Ethnogeneses of People in Indonesian Archipelago, pp. 15-29, Jakarta: LIPI Press.

Simanjuntak, Truman. 2011. Austronesia Prasejarah di Indonesia dalam Austronesia dan Melanesia di Indonesia. Yogyakarta: Ombak 
Sujud, Slamet. "Prasejarah Indonesia: Tinjauan Kronologi dan Morfologi". Jurnal Sejarah dan Budaya, No 2, Desember 2013

Summerhayes, G. 2009. "Obsidian Network Patterns in Melanesia: Sources, Characterisation and Distribution" Bulletin Indo-Pacific Prehistory Association No. 29, pp. 109-123, Canberra: ANU Press.

Wasita. 1999. "Faktor Pendukung Budidaya Padi Masa Prasejarah", Naditira Widya No. 03, hlm. 61-69, Banjarmasin: Balai Arkeologi Banjarmasin.
Yos, Inyos. 1997. Konstruksi Posesif Bahasabahasa Austronesia dan Non Austronesia di Kawasan Timur Indonesia: Studi Bandingan Bahasa Tetun (Timor Timur), Lamaholot (Flores Timur), dan Mai Brat (Kepala Burut), Journal Humsniora $V$.

\section{HASIL DISKUSI}

Tidak ada pertanyaan 